\title{
Pakistan Chronicle
}

By Sir Morrice James. London: Hurst \& Company, 1993, 242 pp.

The book Pakistan Chronicle authored by Morrice James, who had twenty years of experience in South Asia, of which nine years were in Pakistan as deputy and head of the United Kingdom's diplomatic mission-may not be an excellent academic research document, but it deserves credit for certain merits. The psychoanalyses and behavioral studies of some Pakistani military and political elite, especially Ayub, Bhutto, and Zia, are some of the book's outstanding contributions. The book contains excellent discussions on different pacts and treaties Pakistan conducted, such as the Mutual Assistance Pact with the United States (1954), the Indus Water Treaty (1960), the Tashkent Declaration (1966); the crises Pakistan faced, such as the anti-Qadiani Riots in 1953, the Kashmir 
dispute, and the Bangladesh War in 1971; and the Afghan conflict that involved the two superpowers. In the 1960 s, the author observed that India considered Kashmir an integral part of itself and nonnegotiable, and that position has not yet changed.

As the British high commissioner, the author could give a firsthand description of national and international forces that strained Pakistan's relationship with the West, especially Britain and America, and of how Pakistan gradually developed a pro-Chinese foreign policy.

Although the book is titled Pakistan Chronicle, the reader can easily find that the book is really an autobiography of a single intelligent diplomat. The language is forceful and lucid. Sometimes it becomes poetic, as when the author describes his own family, friends, and the nature of the people of Pakistan.

After Muhammad Ali Jinnah, the father of the nation, three leaders mentioned by the author played a crucial role in the making and unmaking of Pakistan. The first is Ayub Khan, the first military dictator and then president, who ruled Pakistan for more than a decade and who wanted national integration through martial law and later by controlled democracy (basic democracy). The second is Bhutto, who tried national integration by implementing Islamic socialism (in which he himself never believed) and coercive personal rule. And the last is Zia, who attempted to introduce the shari'ah (Islamic law) as the rule of law. Unfortunately, all of them failed to understand the will and psychology of the Pakistani nation.

Ayub Khan, who was "personally incorrupt" and whose style was not "self enrichment," "valued and sought to instill in his countrymen honesty, courage, team spirit and hard work" (p. 60). He engaged himself in overdue nation-building tasks and took bold steps in initiating a few important reforms such as land reforms and changes in the laws of inheritance, marriage, and divorce. The signing of the Indus Water Treaty by Nehru and Ayub in 1960 was his remarkable achievement. "It was a high watermark in Indo-Pakistan relations, not reached again in the lifetime of either of them" and without this treaty the then West Pakistan (now the entirety of Pakistan) would have suffered the same fate as East Pakistan (now Bangladesh) whose northern and southern parts have dried up due to the effect of Farakka Dam constructed by India. Unfortunately, the then central government of Pakistan was less enthusiastic in resolving the water dispute of East Pakistan with India.

However, as a born soldier, political solutions to his country's enormous problems were beyond his vision. Rather, his contempt for politicians and Westminister-type democracy for Pakistan was clear and manifest. "How can you run a parliamentary democracy," Ayub asks rhetorically in his memoirs, "when you have big landlords in the country who can influence thousands of votes ... when you have ten or fifteen or more political parties without any program whatsoever ... when you have not even reached the land of universal primary education?" (p. 54). He prevented many politicians under a decree called the Electoral Bodies Disqualification Ordinances (EBDO) from taking part in active politics and arrested many including Suhrawardy, his rival and prominent critic of his new constitution (1958). "A general election, properly conducted, might perhaps have produced a leader (Suhrawardy?) with the requisite proven appeal and consequent authority" (p. 54). Had this been so, as the author insightfully points out, possibly some sort of political solution to keep Pakistan united could have been reached. Instead, Ayub preferred EBDO and restricted democ- 
racy by denying politicians, especially East Pakistani politicians, from taking part in the decision-making process of the central government, ultimately leading to the total bifurcation of East Pakistan from united Pakistan in 1971.

The author's psychoanalysis of Bhutto's mind and actions is remarkable. "Some Pakistanis allege that Bhutto's own status in the household as a child was affected by his mother's lowly birth, and that for some impressionable years he was treated as being unequal to his two elder brothers, the children of Shahnawas, his father's first wife. They say that this scarred Bhutto for life by creating in him a grudge against well-born people, whom in his later days of absolute power in Pakistan, he would take vindictive pleasure in injuring and humiliating" (pp. 72-73). The author, who worked closely with Bhutto, found him a "flawed angel," though "quick-witted" and "articulate." The author asserts that Bhutto's belief in his own infallibility was enough to destroy him. However, the author does not fail to mention the qualities that led Bhutto to swiftly rise to power, the power which he enjoyed from 1957 to 1977 . The author even compared Bhutto's qualities of leadership with those of Churchill and pointed out, "Bhutto certainly had the right qualities for reaching the heights - drive, charm, imagination, quick and penetrating mind, zest for life, eloquence, energy and strong constitution, a sense of humor and a thick skin." $\mathrm{He}$ shared power with Iskander Mirza, Ayub Khan, and Yahya Khan and exercised absolute power from 1971 to 1977.

However, after the "Bangladesh debacle," Pakistan's heterogeneous society which needed Bhutto's strong leadership later turned against him in encouraging "parochial passion, to ethnic anger and bloody-mindedness." In the later years of his regime, Bhutto "concluded that if democracy were to function at all in his unruly and divided country, its manifestations must be limited to those which did not hinder the executive's ability to govern" (p. 199). With this end in view, he took several measures: abolishing Pakistan's traditional type of civil service; creating his personal Federal Security Force that enabled him to deal with politically motivated violence, or the threat of it, without having to resort to the army; and incorporating some Islamic principles in the administration. It became anybody's guess what would happen to Bhutto after he undermined the prestige and authority of the two most powerful institutions in Pakistan's political system - the army and the civil service. On the charge of corruption, murder, atrocities and vote rigging, Bhutto was arrested and later hanged by General Zia ul-Haq, a military ruler whom he had promoted over the heads of more senior officers.

General Zia ul-Haq, a military ruler and devout Muslim, tried to unify Pakistani society through Islam. His introduction of shari'ah into the legal, social, economic, and political order without creating the societal system capable of absorbing a strict Islamic way of life proved counterproductive. By mid1988, when Zia died in a plane crash, the political and social unity of Pakistan "were further off than ever." The renowned Pakistani poet-philosopher, Iqbal, had tried to reconstruct Islam as a rational and moderate religion which was the basis of Jinnah's concept of Islam. "Islam and its idealism have taught us democracy; it has taught equality of man, justice and fairplay," maintained Jinnah. Possibly Jinnah's vision of Islam is best suited to Pakistani society, but no regime has ever tried to implement it.

The epilogue, by Peter Lyon, is helpful in bringing the reader quickly up to speed with recent events, of which the nuclear issue is the most important. 
Pakistan, which was the third largest recipient of American aid and directly served American interests during the long period of confrontation between the Soviet Union and Afghanistan, was denied American aid in 1990 due to the nuclear question. After several years of a "hide-and-seek" policy, Pakistan preferred declaring its possession of nuclear power, such power is as Pakistanis argue, crucial to its defense against India, which also possesses nuclear weapons.

As the title indicates, this book is a chronicle touching many areas of Pakistani society and polity, but it does not have depth of discussion on any one of these areas. Nevertheless, the book is a good supplement to other works writien on Pakistan's politics, society, and people by scholars like K.B. Sayeed, Ralph Braibanti, Talukder Maniruzzaman, and Raunaq Jahan.

U.A.B. Razia Akter Banu Department of Political Science University of Dhaka Dhaka, Bangladesh 